\title{
Enantio and Diastereoselective Addition of Phenylacetylene to Racemic $\alpha$-chloroketones
}

\section{Silvia Alesi, Enrico Emer, Montse Guiteras Capdevila, Diego Petruzziello, Andrea Gualandi and Pier Giorgio Cozzi *}

Alma Mater Studiorum, Dipartimento di Chimica “G: Ciamician”, Università di Bologna, Via Selmi 2, 40126 Bologna, Italy

* Author to whom correspondence should be addressed; E-Mail: piergiorgio.cozzi@unibo.it; Tel.: +39-051-209-9511; Fax: +39-051-209-9456.

Received: 26 May 2011; in revised form: 17 June 2011 / Accepted: 22 June 2011 /

Published: 23 June 2011

\begin{abstract}
In this report, we have presented the first diastereoselective addition of phenylacetylene to chiral racemic chloroketones. The addition is controlled by the reactivity of the chloroketones that allowed the stereoselective reaction to be performed at $-20{ }^{\circ} \mathrm{C}$. Chiral racemic chloroketones are used in the reaction. By carefully controlling the temperature and the reaction time we were able to isolate the corresponding products in moderate yields and with good, simple and predictable facial stereoselection. Our reaction is a rare example of the use of chiral ketones in an enantioselective alkynylation reaction and opens new perspectives for the formation of chiral quaternary stereocenters.
\end{abstract}

Keywords: alkynylation; $(R, R)$-salen; chloroketones; $\mathrm{Me}_{2} \mathrm{Zn}$; phenylacetylene

\section{Introduction}

The addition of carbon nucleophiles to reactive electrophilic functions, such as $\mathrm{C}=\mathrm{O}$ and $\mathrm{C}=\mathrm{N}$ double bonds, is a process of fundamental importance in the development of chemical synthesis [1,2]. Among the various nucleophilic species available, alkynes are excellent reagents for mild and selective C-C bond forming reactions [3-5]. In 2005, we found that mixtures of $\mathrm{Me}_{2} \mathrm{Zn}$ and acetylenes are able to promote the room temperature alkynylation of aldehydes, ketones and imines to furnish propargylic alcohols in good to excellent yields [6]. We have also developed an enantioselective addition of 
phenylacetylene to ketones based on this concept [7]. Since our report, the enantioselective alkynylation of ketones using $\mathrm{R}_{2} \mathrm{Zn}$ as deprotonating agent in the presence of chiral ligands has been the subject of a number of interesting studies [8-13]. However, the diastereoselective and enantioselective addition of acetylides has never been investigated in the case of ketones. Recently, organocatalytic reactions have made possible the simple preparation of optically active $\alpha$-chloro- or $\alpha$-bromoketones, useful starting materials for the preparation of densely functionalized building blocks [14]. However, these useful starting material are difficult to isolate and the subsequent reaction needs to be performed in situ. On the other hand, racemic $\alpha$-haloketones are inexpensive and readily accessible reagents. If the addition of a nucleophile to a racemic haloketone is realized in the presence of a chiral catalyst in a stereoselective manner, highly densely functionalized building blocks containing a quaternary stereocenter could be prepared (Scheme 1).

Scheme 1. Addition of a phenylacetylene to racemic chloroketones.

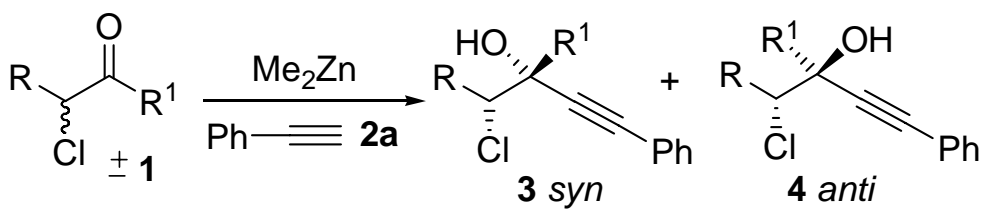

Herein, we report a successful realization of this concept using the $\mathrm{Zn}(\mathrm{Salen})$ promoted addition of acetylene to racemic $\alpha$-chloroketones.

\section{Results and Discussion}

During our studies in the addition of phenylacetylene promoted by $\mathrm{Me}_{2} \mathrm{Zn}$ performed in the absence of air we found that $\alpha$-chloroketones were particularly reactive substrates, and the reaction of 3-chloro2-butanone with phenylacetylene in the presence of $\mathrm{Me}_{2} \mathrm{Zn}$ furnished the corresponding alcohol quantitatively, albeit as a mixture of diastereomers in 52:48 ratio (Scheme 1). In order to improve the diastereoselection we have investigated the reaction in the presence of different ligands 5-9. We have found that a good dr was obtained when the reaction was performed in the presence of the racemic Salen ligand 8. On the other hand, other Schiff bases were also able to increase the dr of the reaction. The possibility to use $\alpha$-chloroketones as substrates for the addition of nucleophiles takes advantage of their enhanced reactivity, and this opens new possibility for stereoselective addition of nucleophiles in organic synthesis [15]. As the reactivity of the chloroketones, compared to other ketones, is remarkable (even in the presence of the Salen ligands), we decided to investigate the reaction performing the addition of phenylacetylene in the presence of enantiopure Salen ligands. We have disclosed the first addition of phenylacetylene to ketones controlled by the Salen ligand [7], and other ligands able to promote the addition of alkyne to ketones were introduced by other groups [8-13]. The addition of phenylacetylene to silylketones promoted by Salen ligands was reported by Chan and Lu [16]. In all these reports it is clearly shown that the reactivity of the ketones is quite different compared to aldehydes and in all the systems reported, long reaction times and a high catalyst loading are required for good stereoselection. The simple stereoselection of the reaction was assigned as anti by chemical correlation with the diastereoisomeric epoxides $\mathbf{1 0}$ (Scheme 2). 
Table 1. Diastereoselective addition of phenylacetylene in the presence of ligands.

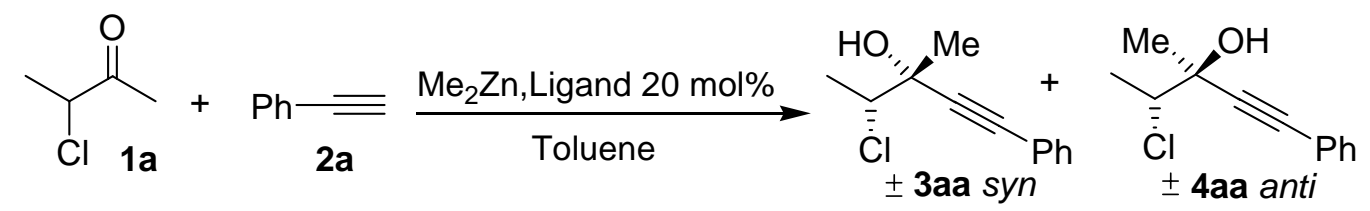

\begin{tabular}{cccc}
\hline Entry $^{\text {a }}$ & syn\% & anti\% \\
\hline $1^{\mathrm{b}}$ & ligand & 52 \\
\hline
\end{tabular}

${ }^{a}$ All the reactions were performed at $\mathrm{rt}$ under nitrogen atmosphere $\mathrm{Me}_{2} \mathrm{Zn}$ (3 equiv.) and phenylacetylene ( 3 equiv.) were added to toluene in a flask under strictly anhydrous conditions, and stirred $10 \mathrm{~min}$, then the ligand $(20 \mathrm{~mol} \%)$ was added and the reaction mixture and stirred for 5-10 min. Finally, the chloroketone (1 equiv.) was added. The reaction was stirred under completion (monitored by TLC, 16-24 h) and quenched with water. The dr was determined on the crude reaction mixture by ${ }^{1} \mathrm{H}-\mathrm{NMR}$. ${ }^{\mathrm{b}}$ The reaction was performed in the presence of $\mathrm{Me}_{2} \mathrm{Zn}$ without ligands. ${ }^{c}$ The reaction was performed with lithium phenylacetylide, prepared by the addition of 1 equiv. of $n$-BuLi to 1.1 equiv. of phenylacetylene at $0{ }^{\circ} \mathrm{C}$.

The mixture of the diasteroisomers was transformed to the epoxides by treatment with $t \mathrm{BuOK}$ in THF at $-20{ }^{\circ} \mathrm{C}$. The ${ }^{13} \mathrm{C}$ - and ${ }^{1} \mathrm{H}-\mathrm{NMR}$ data of the mixture of isolated epoxides were compared with literature data [17]. It is worth adding that the reaction of the lithium acetylide to the chloroketone furnished the desired product with high stereoselectivity (Table 1, entry 7). The major diastereoisomer derived by the attack of the alkyne to the chiral chloroketone can be rationalized by invoking the Felkin-Anh model [18-22]. While the reaction with $\mathrm{Me}_{2} \mathrm{Zn}$ afforded the desired products with low 
stereoselectivity (Table 1, entry 1), the the $\mathrm{Zn}(\mathrm{Salen})$ formed in situ controls the stereoselection through the complexation of the chloroketone to the zinc Lewis acidic center. The simple anti diastereoselection obtained in the case lithium phenylacetylene and with ligand mediated addition of zinc phenylacetylide can be rationalized by a Felkin-Anh transition state in which the nucleophilic alkyne attaches the carbonyl group in a conformation in which the chlorine is the larger group (Scheme 2, Figure A).

Scheme 2. Assignment of the relative configuration of the diastereoisomers obtained by addition of phenylacetylene to a racemic chloroketone.

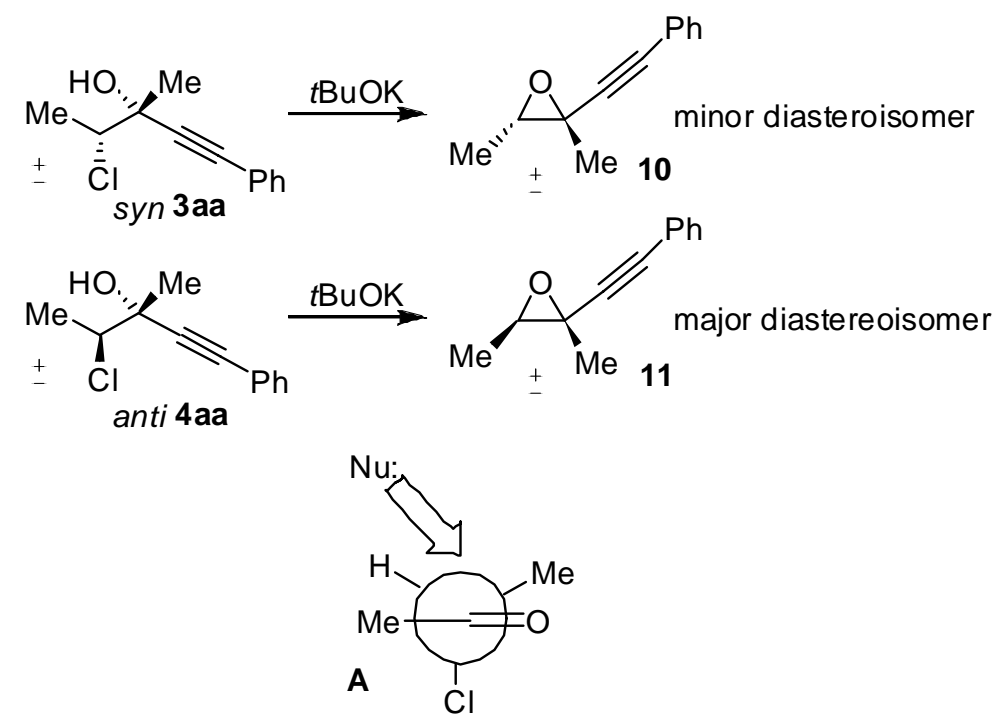

The preliminary results obtained with 1a gave us the indication that the reactivity of the chloroketone was very high, and that it was possible to reduce the temperature for the stereoselective reaction. It is noteworthy that the Salen catalyzed addition of phenylacetylene to ketone is performed at $\mathrm{rt}$ and no addition occurs with aliphatic or aromatic ketones at lower temperatures $\left(0{ }^{\circ} \mathrm{C}\right.$ or below $)$. The increased reactivity of chloroketone thus allowed the investigation of the reaction at reduced temperature. Using commercially available racemic 3-chlorobutanone (1a) as a model substrate, we have performed the reaction at low temperature, in the presence of the $(R, R)$-Salen 8 and in Table 2 we report the results of this investigation. The reaction is stereoselective and the corresponding adducts can be isolated in high enantiomeric and good diastereoisomeric excesses, albeit in low to moderate yield. The enantiomeric excess obtained in the reaction is a function of the conversion. In fact, in order to keep the stereoselection very high it is important to stop the reaction after 60 hours at $-20{ }^{\circ} \mathrm{C}$; if the reaction is conducted at $0{ }^{\circ} \mathrm{C}$, the adduct is isolated with a dr of $4: 1$ in favor of the anti diastereoisomer in good yield (60-70\%) but in very low ee. If the reaction is not stopped at $-20{ }^{\circ} \mathrm{C}$ after $60 \mathrm{~h}$, the conversion is increased and the yield can be higher than $50 \%$, but the facial stereoselection of the isolated diastereoisomers was quite low. Performing the reaction at increased temperature $\left(>0{ }^{\circ} \mathrm{C}\right)$ the syn and anti stereoisomers are again isolated with good yield but in very low enantiomeric excess. This is straightforwardly explained by considering the reactivity of the chloroketone and the background reaction. At room temperature the $\mathrm{Me}_{2} \mathrm{Zn}$ promoted addition of phenylacetylene to ketone is occurring without the catalysis of the $\mathrm{Zn}$ (Salen) complexes [6]. The conversion and the isolated yield of the products can be improved at the expense of the enantiomeric excess. In order to increase the reaction 
rate of the reaction the excess of $\mathrm{Me}_{2} \mathrm{Zn}$, and phenylacetylene was adjusted, and a compromise between reactivity and stereoselectivity was finally obtained. Similar reaction with aliphatic or aromatic ketones do not give any traces of product if they are conducted at $-20{ }^{\circ} \mathrm{C}$, even in the presence of the Salen ligand. The best conditions in the optimization were found when 4.5 equivalent of $\mathrm{Me}_{2} \mathrm{Zn}$ and $30 \mathrm{~mol} \%$ of Salen were employed in the reaction. The Salen and the $\mathrm{Me}_{2} \mathrm{Zn}$ were mixed at $\mathrm{rt}$ for 1 hour before being to add the chloroketone at low temperature. The quantity of solvent was also important in order to enhance the enantiomeric excess. The reaction was performed without stirring, at $-20^{\circ} \mathrm{C}$ for 60 hours.

Table 2. Stereoselective addition of phenylacetylene to 3-chlorobutanone promoted by $(R, R)$-Salen ligand.

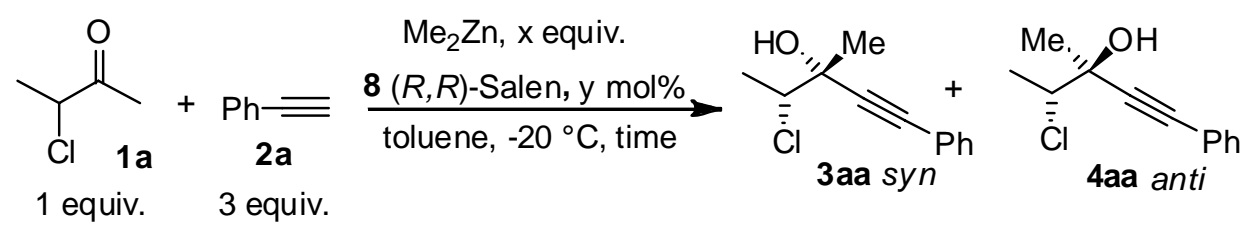

\begin{tabular}{cccccccccc}
\hline Entry $^{\text {a }}$ & $\begin{array}{c}\mathbf{M e}_{\mathbf{2}} \mathbf{Z n} \\
\text { (x equiv.) }\end{array}$ & $\begin{array}{c}\text { Salen } \\
\text { (y mol \%) }\end{array}$ & $\begin{array}{c}\text { solvent } \\
\mathbf{( m L )}\end{array}$ & $\mathbf{d r}^{\mathbf{b}}$ & $\mathbf{T}$ (h) & ${\text { ee } \text { anti }^{\mathbf{c}}}^{\text {ee syn }^{\mathbf{c}}}$ & Yield $^{\mathbf{d}}$ \\
\hline 1 & 3 & 20 & 1 & $78: 22$ & 72 & 70 & 40 & 25 \\
2 & 5 & 20 & 1 & $77: 23$ & 72 & 79 & 45 & 45 \\
3 & 6 & 20 & 1 & $76: 24$ & 60 & 50 & 50 & 53 \\
4 & 4.5 & 30 & 1.5 & $82: 18$ & 60 & 90 & 82 & 25 \\
5 & 4.5 & 10 & 1 & $83: 17$ & 60 & 50 & 67 & 69 \\
\hline
\end{tabular}

a All the reactions were performed at $-20{ }^{\circ} \mathrm{C}$ under nitrogen and stopped after the time indicated.

${ }^{\mathrm{b}}$ The diastereoisomeric ratio was evaluated on the crude reaction mixture by ${ }^{1} \mathrm{H}-\mathrm{NMR} .{ }^{\mathrm{c}}$ The enantiomeric excess was evaluated by chiral HPLC analysis (see experimental part for the conditions) ${ }^{\mathrm{d}}$ Isolated yield $(s y n+a n t i)$ after chromatographic purification.

Delighted by the results obtained with 3-chlorobutanone, we decided to investigate the generality of our reaction, studying other different chloroketones. The substrates were prepared using a methodology developed by De Kimpe [23], illustrated in Scheme 3.

Scheme 3. Preparation of chloroketones.

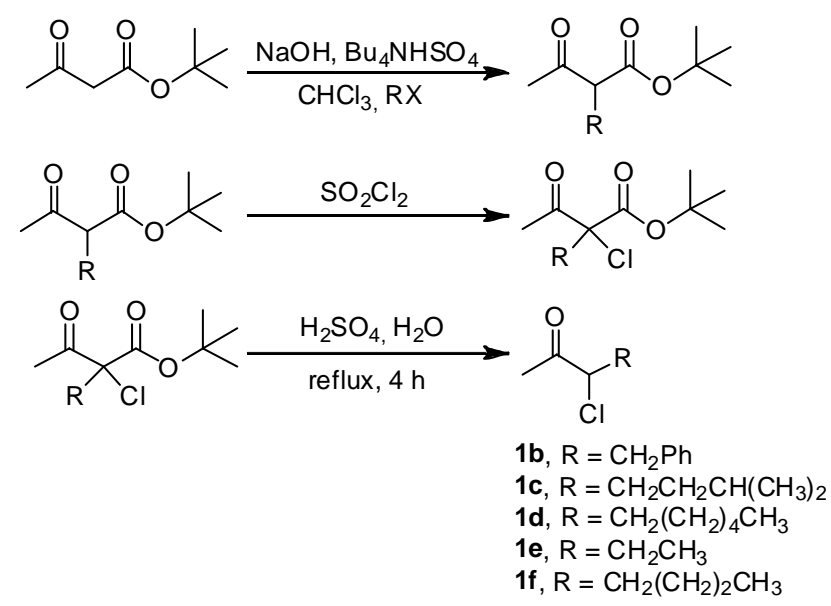


The corresponding ketones were prepared without difficulties in large scale, and were purified by distillation. The ketones $\mathbf{1 b}-\mathbf{f}$ was used in the reaction with phenylacetylene promoted by $\mathrm{Me}_{2} \mathrm{Zn}$, by using the conditions optimized for the substrate 1a and the results are reported in Table 3.

Table 3. Stereoselective addition of phenylacetylene to a series of $\alpha$-chloroketones promoted by $(R, R)$-Salen ligand.

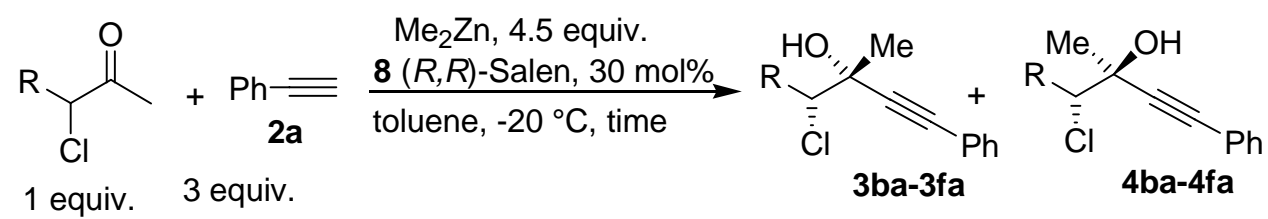

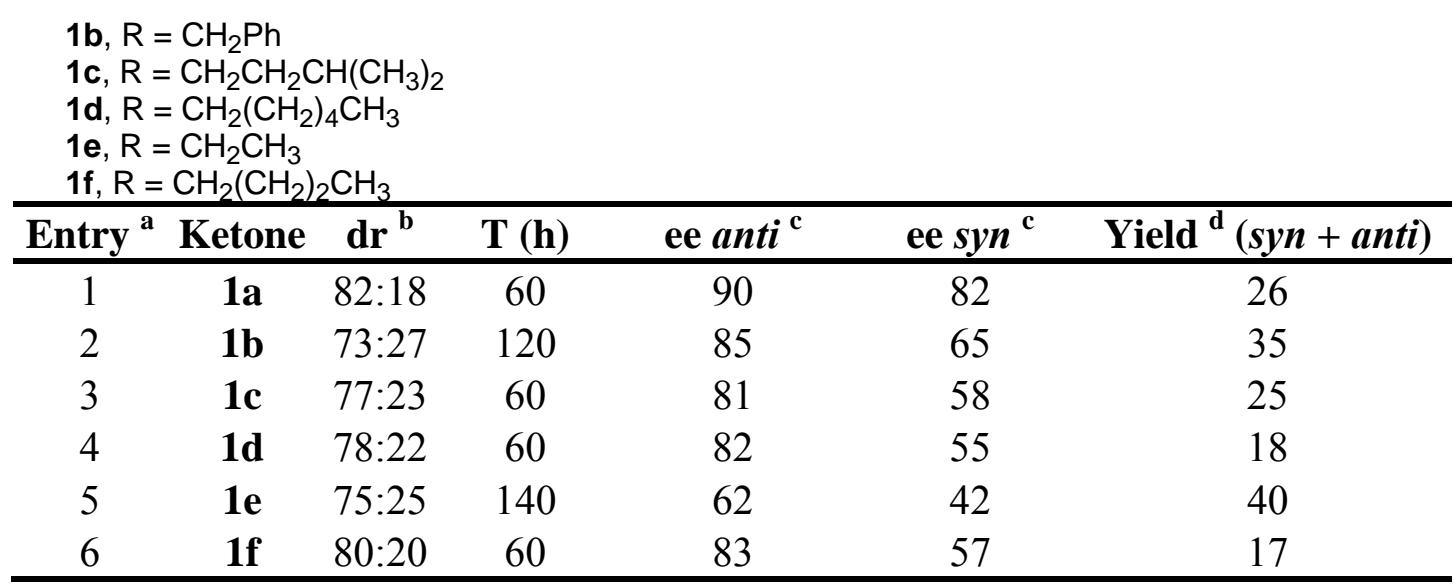

${ }^{\text {a }}$ All the reactions were performed at $-20{ }^{\circ} \mathrm{C}$ under nitrogen and stopped after the time indicated.

${ }^{\mathrm{b}}$ The diastereoisomeric ratios were evaluated on the crude reaction mixture by ${ }^{1} \mathrm{H}-\mathrm{NMR}$. ${ }^{\mathrm{c}}$ The enantiomeric excess was evaluated by chiral HPLC analysis (see experimental part for the conditions) ${ }^{\mathrm{d}}$ Isolated yield (syn + anti) after chromatographic purification.

Generally, the yields of the reaction are quite moderate, because the reaction was stopped in order to obtain the highest enantiomeric excesses for the isolated adducts. The steric hindrance of the ketones does not seem significant in the controlling the enantiomeric excess. The reaction also works in the case of other haloketones, e.g. $\alpha$.-fluoroketones, Scheme 4 Although was possible to perform the reaction with other haloketones, generally the results were inferior compared to the chloroketones.

Scheme 4. Stereoselective addition of phenylacetylene to the fluoroketone $\mathbf{1 g}$.

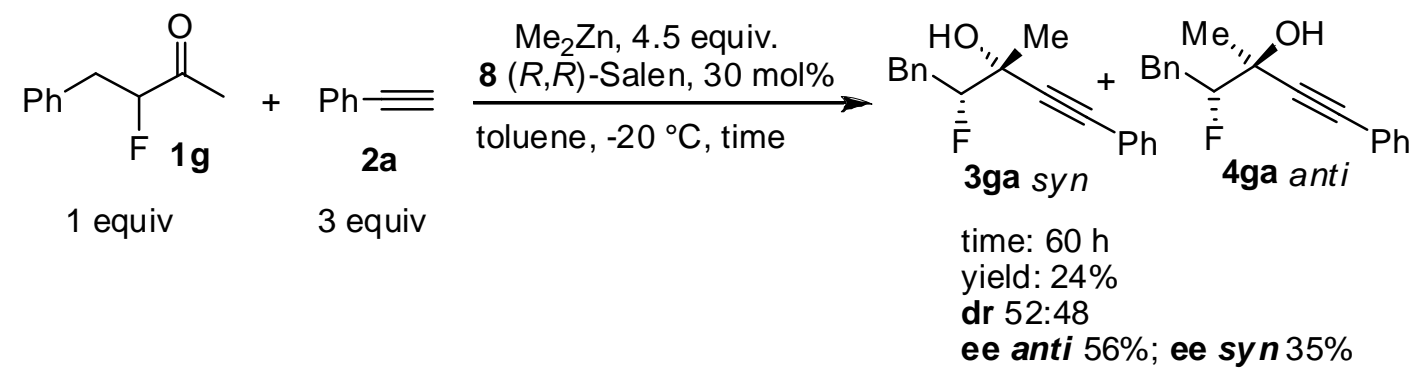

Concerning the possibility of using different substituted acetylenes in our reactions, we have briefly investigated the reaction employing alkyl and silyl substituted acetylenes under the general conditions developed for 3-chlorobutanone, and the data obtained are reported in Table 4. As is possible to evince 
by the data, the reactivity of the acetylenes $\mathbf{2 b}$-d was quite lower compared to phenylacetylene, and products were isolated in low yield and with minor levels of stereoselectivity.

Table 4. Stereoselective addition of substituted acetylenes to 3-chlorobutanone promoted by $(R, R)$-Salen ligand.

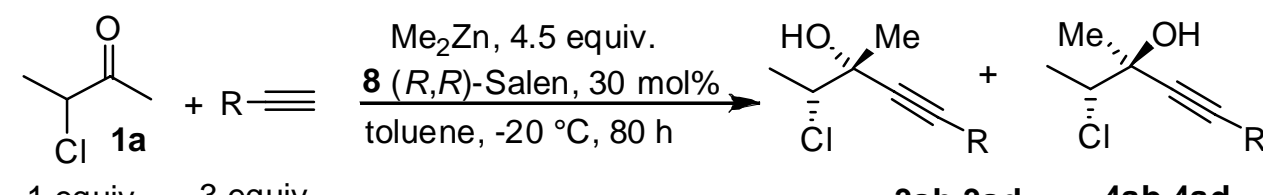

1 equiv. $\quad 3$ equiv.

3ab-3ad 4ab-4ad

\begin{tabular}{|c|c|c|c|c|c|}
\hline & $\begin{array}{l}\mathbf{2 b}, \mathrm{R}=\mathrm{CH}_{2} \mathrm{Br} \\
\mathbf{2 c}, \mathrm{R}=\mathrm{SiMe}_{3} \\
\mathbf{2 d}, \mathrm{R}=\left(\mathrm{CH}_{2}\right)_{3} \mathrm{Cl}\end{array}$ & & & & \\
\hline Entry $^{a}$ & Alkyne & $d r^{b}$ & ee $a n t i^{\mathrm{c}}$ & ee $\operatorname{syn}{ }^{c}$ & Yield $^{\mathrm{d}}(\operatorname{syn}+$ anti) \\
\hline 1 & $\mathrm{HCCCH}_{2} \mathrm{Br}, \mathbf{2 b}$ & $64: 36$ & 66 & 53 & 25 \\
\hline 2 & $\mathrm{HCCSiMe}_{3}, \mathbf{2 c}$ & $75: 25$ & 75 & 62 & 15 \\
\hline 3 & $\mathrm{HCC}\left(\mathrm{CH}_{2}\right)_{3} \mathrm{CH}_{3}, \mathbf{2 d}$ & $83: 17$ & 68 & 41 & 20 \\
\hline
\end{tabular}

a All the reactions were performed at $-20{ }^{\circ} \mathrm{C}$ under nitrogen atmosphere, by adding $\mathrm{Me}_{2} \mathrm{Zn}$ (4 equiv) to Salen $(30 \mathrm{~mol} \%$ ) at $\mathrm{rt}$. Then the alkyne was added and the mixture was cooled to $-25{ }^{\circ} \mathrm{C}$. The ketone 1a was added and the reaction kept without stirring for $80 \mathrm{~h}$ at $-20{ }^{\circ} \mathrm{C}$. ${ }^{\mathrm{b}}$ The diastereoisomeric ratios (anti: syn) were evaluated on the crude reaction mixture by ${ }^{1} \mathrm{H}-\mathrm{NMR} .{ }^{\mathrm{c}}$ The enantiomeric excess was evaluated by chiral HPLC analysis (see experimental part for the conditions) ${ }^{\mathrm{d}}$ Isolated yield $(s y n+a n t i)$ after chromatographic purification.

We have established the absolute configuration of the products as indicated in Scheme 5. Enantiopure 4-phenyl-3-chloro-butan-2-one was prepared from the corresponding (S)-3-phenyl-2chloropropanal following the procedure published by De Kimpe [24].

Scheme 5. Assignment of absolute configuration of the syn and anti stereoisomers on the basis of diastereoselective addition to the enantioenriched $(S)-\mathbf{1 b}$.

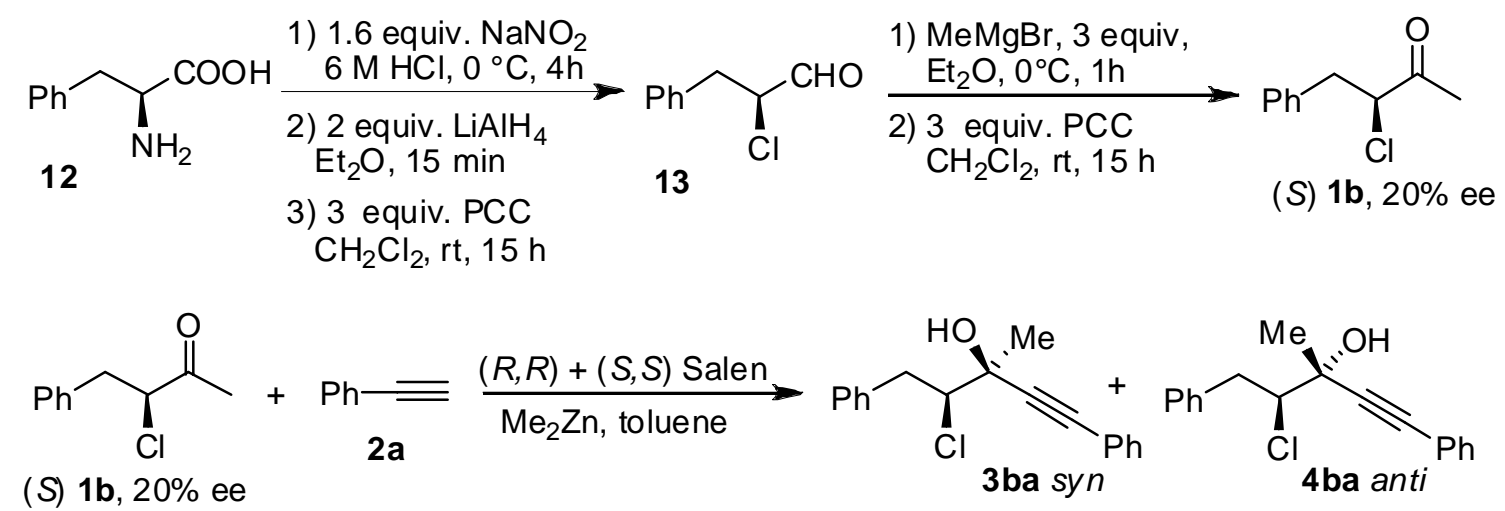

The $(S)$-chloroaldehyde 13 was obtained in moderate yield from the aminoacid 12, and used without purification in the subsequent steps. (S)-chloroaldehyde 11 was treated with $\mathrm{MeMgBr}$ at $0{ }^{\circ} \mathrm{C}$, to give the corresponding secondary alcohol that was directly oxidized with PCC to the ketone $\mathbf{1 b}$. HPLC analysis performed on the chloroketone established that the $(S)$-chloroketone was obtained with poor 
enantiomeric excess of $20 \%$, due to the racemization. Optically active chloroaldehydes have been used in the diastereoselective addition of organometallic reagents [25-29]. The addition of Grignard reagents to chloroaldehyde was reported to give good yield and moderate diastereoisomeric excess both in $\mathrm{Et}_{2} \mathrm{O}$ or in THF, and racemization of the aldehydes seems not to occur [30]. Perhaps, the racemization of our substrate is occurring during the oxidation step. Nevertheless, the enantiomeric excess obtained for the chloroketone $\mathbf{1 b}$ was sufficient to assign the absolute configuration of the products obtained in the alkynylation reactions. The reaction with the chloroketone $\mathbf{1 b}$ was performed in the presence of $20 \mathrm{~mol} \%$ of a racemic mixture of $(R, R)$ and $(S, S)$-Salen ligand (Scheme 5$)$. AS in the case of the ketone 1a, the diastereoisomeric ratio of products 3ba and $\mathbf{4 b a}$ bbtained was 4:1 in favor of the anti diastereoisomer. The configuration of the stereogenic centers for all the diastereoisomers was assigned by comparison of the HPLC traces obtained for the racemic and for the $(S)$-chloroketone. The absolute configuration of the major diastereoisomer obtained in the reaction with $(R, R)$-Salen and racemic $\mathbf{1 b}$ was $3 S, 4 R$. The absolute configuration for all the products was assigned by analogy, taking in consideration that for all the chloroketones the anti and syn products have similar HPLC retention times. Is worth adding that the absolute configuration obtained in the case of the chloroketone is opposite to that in the Salen mediated addition of phenylacetylene to aliphatic and aromatic ketones. In the case of aliphatic and aromatic ketones the $(R, R)$-Salen is inducing the formation of a new stereogenic tertiary alcohol of $(S)$ configuration [31]. However, the reaction conditions for the alkynylation reactions in the case of the chloroketones are completely different from those of the alkynylations of aromatic and aliphatic ketones. In addition, the presence of the stereogenic center of the chiral chloroketone can induce a preferential coordination of one enantiomer of the chloroketone as depicted in the model of Figure 1. In order to study the possibility of kinetic resolution, two enantiomeric chloroketones $\mathbf{1 b}$ were separated by chiral HPLC analysis. When the reaction was performed using 2 or more equivalents of chloroketone $\mathbf{1 b}$, the excess of chloroketone was isolated after the reaction performed in the presence of $(R, R)$-Salen ligand and it was analyzed by chiral HPLC. The ketone $\mathbf{1 b}$ was isolated with no traces of enantioenrichment. In addition, when the optically active (S)-1b $\left(20 \%\right.$ ee) was treated with 2 equivalent of $\mathrm{Me}_{2} \mathrm{Zn}$ in toluene and the solution obtained was stirred at $\mathrm{rt}$ for two days, after quenching no reaction of $\mathrm{Me}_{2} \mathrm{Zn}$ with the choroketones took place. According to the HPLC analysis of the crude reaction mixture the $(S)$ chloroketone undergoes no racemization in the presence of $\mathrm{Me}_{2} \mathrm{Zn}$, as the enantiomeric excess of the chloroketones was unchanged. Therefore, the result obtained in the reaction of racemic chloroketones is not determined by a racemization of the chloroketones and the selective reaction of one enantiomer. The observed facial stereoselection could result from a preferential coordination of one enantiomer of the chloroketone to the $\mathrm{Zn}$ (Salen) complex, with this preferential stereoisomer reacting at a faster rate. It is worth adding that the analysis of the reaction is complicated by the fast background reaction, which has hampered any attempt to prove that the reaction was taking place via a kinetic resolution with preferential coordination of the $(R)$ chloroketones. The fast background reaction is favored by excess of ketones, an excess that is necessary to investigate the kinetic resolution. For example, when the reaction was performed using 3 equiv of $1 \mathbf{a}$ in the presence 1 equiv of phenylacetylene and 1.4 equiv. of $\mathrm{Me}_{2} \mathrm{Zn}$, the corresponding adducts were isolated with $15 \%$ ee for the anti stereoisomer. Performing careful analysis and selecting different reaction times and concentrations, we were not able to measure any enrichment of the starting chloroketones $\mathbf{1 b}$. However, further studies are still necessary in order to 
explain and understand the results obtained in the stereoselective addition of phenylacetylene to haloketones, and work is in progress towards this objective.

Figure 1. Stereoselective addition of phenylacetylene on the chloroketone.

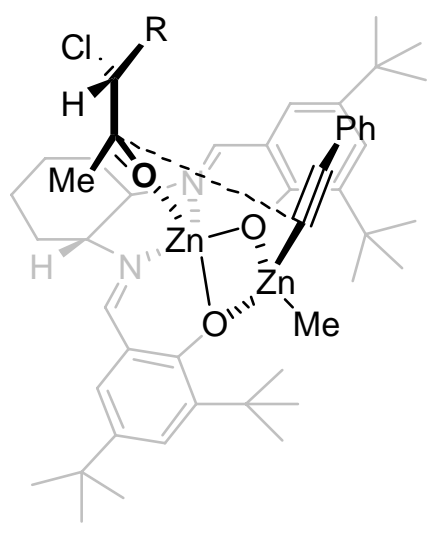

\section{Experimental}

\subsection{General}

${ }^{1}$ H-NMR spectra were recorded on Varian Gemini 200 and Varian Mercury 400 spectrometers. Chemical shifts are reported in ppm from TMS with the solvent resonance as the internal standard (deuterochloroform: $\delta=7.27 \mathrm{ppm}$ ). Data are reported as follows: chemical shift, multiplicity ( $\mathrm{s}=$ singlet, $\mathrm{d}=$ duplet, $\mathrm{t}=$ triplet, $\mathrm{q}=$ quartet, $\mathrm{bs}=$ broad singlet, $\mathrm{m}=$ multiplet), coupling constants (Hz). ${ }^{13} \mathrm{C}$-NMR spectra were recorded on Varian Gemini 200 and Varian Mercury 400 spectrometers. Chemical shifts are reported in ppm from TMS with the solvent as the internal standard (deuterochloroform: $\delta=77.0 \mathrm{ppm}$ ). GC-MS spectra were taken by EI ionization at $70 \mathrm{eV}$ on a Hewlett-Packard 5971 with GC injection. They are reported as: $m / z$ (rel. intense). LC-electrospray ionization mass spectra were obtained with Agilent Technologies MSD1100 single-quadrupole mass spectrometer. Chromatographic purification was done with 240-400 mesh silica gel. Determination of enantiomeric excesses were performed on an Agilent Technologies 1200 instrument equipped with a variable wave-length UV detector, using Daicel Chiralpak columns $(0.46 \mathrm{~cm} \mathrm{I.D.} \times 25 \mathrm{~cm})$ and HPLC grade isopropanol and $n$-hexane were used as the eluting solvents. Melting points were determined with a Bibby Stuart Scientific SMP 3 Melting Point Apparatus and are not corrected. All reactions were carried out under inert gas and anhydrous conditions. Anhydrous solvents were supplied by Aldrich in Sureseal ${ }^{\circledR}$ bottles and used avoiding purification. $\mathrm{Me}_{2} \mathrm{Zn} 2 \mathrm{M}$ in toluene was supplied in Aldrich Sureseal ${ }^{\circledR}$ bottles and used as received. $(R, R)$-Salen is commercially available from Aldrich. Phenyacetylene was purchased by Aldrich and used as received. 3-Chlorobutanone is commercially available and was used after distillation. The chloroketones 1b-1f were prepared according to the literature procedure described by De Kimpe [23], and were obtained in 16-20\% yield (three reactions). The fluoroketone $\mathbf{1 g}$ was obtained as reported in literature [32]. 
3-Chloro-4-phenylbutan-2-one (1b). $\mathrm{C}_{10} \mathrm{H}_{11} \mathrm{ClO} \mathrm{MW}=182.65 .{ }^{1} \mathrm{H}-\mathrm{NMR}\left(\mathrm{CDCl}_{3}, 300 \mathrm{MHz}\right) \delta: 2.35$ (s, 3H); $3.11(\mathrm{dd}, 1 \mathrm{H}, J=8.1,14.4 \mathrm{~Hz}) ; 3.37(\mathrm{dd}, 1 \mathrm{H}, J=6.3,14.4 \mathrm{~Hz}) ; 4.44(\mathrm{dd}, 1 \mathrm{H}, J=6.3,8.1 \mathrm{~Hz})$. 7.4-7.2 (m, 5H). ${ }^{13} \mathrm{C}-\mathrm{NMR}\left(\mathrm{CDCl}_{3}, 75 \mathrm{MHz}\right) \delta: 26.8 ; 39.8 ; 63.8 ; 127.2 ; 128.2 ; 128.6 ; 129.3$.

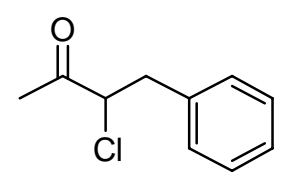

3-Chloro-6-methyleptan-2-one (1c). $\mathrm{C}_{8} \mathrm{H}_{15} \mathrm{ClO} \mathrm{MW}=162.08 .{ }^{1} \mathrm{H}-\mathrm{NMR}\left(\mathrm{CDCl}_{3}, 300 \mathrm{MHz}\right) \delta: 0.92$ $(\mathrm{d}, 3 \mathrm{H}, J=6.6 \mathrm{~Hz}) ; 0.97(\mathrm{~d}, 3 \mathrm{H}, J=6.6 \mathrm{~Hz}) ; 1.8-1.71(\mathrm{~m}, 5 \mathrm{H}) ; 2.32(\mathrm{~s}, 3 \mathrm{H}) ; 4.22(\mathrm{dd}, 1 \mathrm{H}, J=6.0$, $9.0 \mathrm{~Hz}) .{ }^{13} \mathrm{C}-\mathrm{NMR}\left(\mathrm{CDCl}_{3}, 75 \mathrm{MHz}\right) \delta: 21.2 ; 22.7,25.0,25.6 ; 62.7,203.5$.<smiles>CC(=O)C(Cl)CCC(C)C</smiles>

3-Chlorononan-2-one (1d). $\mathrm{C}_{9} \mathrm{H}_{17} \mathrm{ClO} \mathrm{MW}=148.63 .{ }^{1} \mathrm{H}-\mathrm{NMR}\left(\mathrm{CDCl}_{3}, 300 \mathrm{MHz}\right) \delta: 0.88(\mathrm{~m}, 3 \mathrm{H})$; $2.0-1.20(\mathrm{~m}, 10 \mathrm{H}) ; 2.31$, (s, 3H); $4.17(\mathrm{dd}, 1 \mathrm{H}, J=5.4,8.1 \mathrm{~Hz}) .{ }^{13} \mathrm{C}-\mathrm{NMR}\left(\mathrm{CDCl}_{3}, 75 \mathrm{MHz}\right) \delta: 13.9$; $22.4 ; 25.8 ; 25.9 ; 28.5 ; 28.9 ; 31.4 ; 33.7 ; 64.3 ; 203.4$.<smiles>CCCCCCC(Cl)C(C)=O</smiles>

3-Chloropentan-2-one (1e). $\mathrm{C}_{5} \mathrm{H}_{9} \mathrm{ClO} \mathrm{MW}=120.58 .{ }^{1} \mathrm{H}-\mathrm{NMR}\left(\mathrm{CDCl}_{3}, 300 \mathrm{MHz}\right) \delta: 1.02(\mathrm{t}, 3 \mathrm{H}$, $J=7.8 \mathrm{~Hz}) ; 2.1-1.8(\mathrm{~m}, 2 \mathrm{H}) ; 2.31(\mathrm{~s}, 3 \mathrm{H}) ; 4.12(\mathrm{dd}, 1 \mathrm{H}, J=5.4,7.8 \mathrm{~Hz}) .{ }^{13} \mathrm{C}-\mathrm{NMR}\left(\mathrm{CDCl}_{3}, 75 \mathrm{MHz}\right)$ $\delta: 10.5 ; 25.9 ; 27.2 ; 65.7 ; 203.3$.<smiles>CCC(Cl)C(C)=O</smiles>

3-Chloroheptan-2-one (1f). $\mathrm{C}_{7} \mathrm{H}_{13} \mathrm{ClO} \mathrm{MW}=148.63 .{ }^{1} \mathrm{H}-\mathrm{NMR}\left(\mathrm{CDCl}_{3}, 300 \mathrm{MHz}\right) \delta: 0.92$ (t, 3H, $J=6.6 \mathrm{~Hz}) ; 1.40-1.31(\mathrm{~m}, 4 \mathrm{H}) ; 2.0-1.80(\mathrm{~m}, 2 \mathrm{H}) ; 2.31(\mathrm{~s}, 3 \mathrm{H}) ; 4.16(\mathrm{dd}, 1 \mathrm{H}, J=5.7,8.1 \mathrm{~Hz})$. ${ }^{13} \mathrm{C}-\mathrm{NMR}\left(\mathrm{CDCl}_{3}, 75 \mathrm{MHz}\right) \delta: 13.8 ; 22.0 ; 25.8 ; 28.1 ; 33.5 ; 64.3 ; 203.5$.<smiles>CCCCC(Cl)C(C)=O</smiles>

\subsection{Addition of Alkynes to Chloroketones}

General procedure: In a flask under nitrogen containing a solution of $(R, R)$ Salen $(0.075 \mathrm{mg}$, $0.135 \mathrm{mmol})$ in toluene $(1 \mathrm{~mL})$, a $2 \mathrm{M}$ solution of $\mathrm{Me}_{2} \mathrm{Zn}$ is added under stirring $(1 \mathrm{~mL}, 2.025 \mathrm{mmol})$. The mixture is stirred $10 \mathrm{~min}$ at $\mathrm{rt}$, then phenylacetylene $(0.15 \mathrm{~mL}, 1.35 \mathrm{mmol})$ was added. The mixture was stirred $1 \mathrm{~h}$ at $\mathrm{rt}$, then the solution was cooled to $-25^{\circ} \mathrm{C}$. Chloroketone $(0.45 \mathrm{mmol})$ was 
added, and the mixture was kept at $-20{ }^{\circ} \mathrm{C}$ without stirring for $60 \mathrm{~h}$. The reaction was quenched with water at $-20{ }^{\circ} \mathrm{C}$, then the reaction was diluted with $\mathrm{Et}_{2} \mathrm{O}$. The organic phase (yellow) was separated and the aqueous phase was extracted with $\mathrm{Et}_{2} \mathrm{O}$. The organic phases were reunited, evaporated under reduce pressure and purified by chromatography.

4-Chloro-3-methyl-1-phenylpent-1-yn-3-ol (3aa/4aa). $\mathrm{C}_{12} \mathrm{H}_{13} \mathrm{ClO} \mathrm{MW}=208.68 .{ }^{1} \mathrm{H}-\mathrm{NMR}\left(\mathrm{CDCl}_{3}\right.$, $200 \mathrm{MHz}$ ) $\delta: 1.67$ (maj, s, 3H); 1.68 (min, s, 3H); 1.72 (d, 3H, $J=6.6 \mathrm{~Hz}) ; 1.61$ (min, brs, $1 \mathrm{H}) ; 2.86$ (maj, brs, 1H); 4.16 (maj, q, 1H, $J=6.6 \mathrm{~Hz}$ ); 4.23 (min, q, 1H, $J=7.0 \mathrm{~Hz}$ ); 7.35-7.30 (m, 3H); 7.50-7.46 (m, 2H). ${ }^{13} \mathrm{C}-\mathrm{NMR}\left(\mathrm{CDCl}_{3}, 50 \mathrm{MHz}\right) \delta: 20.0$ (min); 20.7 (maj); 25.5 (min); 26.7 (maj); 65.2 (min); 68.8 (maj); 71.3 (min); 71.6 (maj); 84.8 (min); 85.1 (maj); 88.7 (maj); 89.7 (min); 122.2; 128.2; 128.6; 131.7. The ee was determined by HPLC analysis (Daicel Chiralcel OD column: hexane/ $i-\mathrm{PrOH}$ 98.5:1.5, flow rate $0.50 \mathrm{~mL} / \mathrm{min}, 27^{\circ} \mathrm{C}, \lambda=214,250 \mathrm{~nm}$ : anti diasteroisomer (4aa) $\tau_{\text {major }}=23.13 \mathrm{~min}$, $\tau_{\text {minor }}=41.21 \mathrm{~min}$; syn diasteroisomer (3aa) $\tau_{\text {major }}=28.58 \mathrm{~min} ., \tau_{\text {minor }}=45.83 \mathrm{~min}$. anti:syn 82:18. ee anti $85 \%$. ee syn 65\%. GCMS: 15.07 (maj); 15.16 (min). HMRS calcd for $\mathrm{C}_{12} \mathrm{H}_{13} \mathrm{ClO}$ : 208.0655; found 208.0659 .

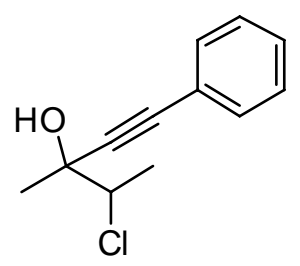

2,3-Dimethyl-2-phenylethynyloxirane (10/11). $\mathrm{C}_{12} \mathrm{H}_{13} \mathrm{ClO} \mathrm{MW}=172.22 .{ }^{1} \mathrm{H}-\mathrm{NMR}\left(\mathrm{CDCl}_{3}, 200 \mathrm{MHz}\right)$ $\delta: 1.38$ (maj, d, 3H, $J=5.6 \mathrm{~Hz}$ ); 1.52 (min, d, 3H, $J=5.2 \mathrm{~Hz}$ ); 1.61 (maj, s, 3H); 1.65 (min, s, 3H); 3.08 (min, q, $J=5.2 \mathrm{~Hz}$ ); 3.39 (maj, q, 1H, $J=5.4 \mathrm{~Hz}$ ); 7.35-7.30 (m, 3H); 7.50-7.46 (m, 2H). ${ }^{13} \mathrm{C}-\mathrm{NMR}\left(\mathrm{CDCl}_{3}, 50 \mathrm{MHz}\right) \delta$ : 13.7 (maj); 15.6 (min); 18.3 (maj); 23.3 (min); 51.2 (maj); 53.2 (min); 60.9 (maj); 61.4 (min); 81.6; 89.9; 122.2; 128.2; 128.5; 131.8.

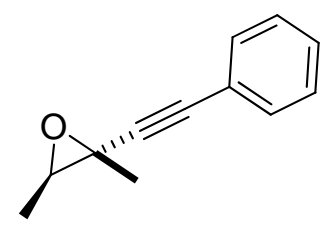

4-Chloro-3-methyl-1,5-diphenylpent-1-yn-3-ol (3ba/4ba). $\mathrm{C}_{18} \mathrm{H}_{17} \mathrm{ClO} \quad \mathrm{MW}=284.78 .{ }^{1} \mathrm{H}-\mathrm{NMR}$ $\left(\mathrm{CDCl}_{3}, 300 \mathrm{MHz}\right) \delta: 1.68$ (s, 3H); 2.85 (min, dd, 1H, $\left.J=11.1,14.4 \mathrm{~Hz}\right) ; 2.99$ (maj, dd, $1 \mathrm{H}, J=10.8$, 14.4 Hz); 3.55-3.41 (m, 1H); 4.09 (min, dd, 1H, $J=2.4,11.1 \mathrm{~Hz}$ ); 4.19 (maj, dd, 1H, $J=2.7,10.8 \mathrm{~Hz}$ ); 7.60-7.20 (m, 10H). ${ }^{13} \mathrm{C}-\mathrm{NMR}\left(\mathrm{CDCl}_{3}, 75 \mathrm{MHz}\right) \delta: 26.2$ (maj); 26.8 (min); 27.3; 39.8 (min); 40.1 (maj); 71.2 (min); 71.3 (maj); 71.4 (min); 72.7 (maj); 85.5 (min); 85.6 (maj); 89.1 (maj); 89.4 (min); $122.1 ; 126.8 ; 128.3 ; 128.4 ; 128.7 ; 129.3 ; 131.8 ; 137.9$ (maj); 138.0 (min). The ee was determined by HPLC analysis Daicel Chiralcel OD column: hexane $/ i-\mathrm{PrOH} 97.5: 2.5$, flow rate $0.50 \mathrm{~mL} / \mathrm{min}, 27^{\circ} \mathrm{C}$, $\lambda=214,250 \mathrm{~nm}$ : anti diasteroisomer (4ba) $\tau_{\text {major }}=21.97 \mathrm{~min}, \tau_{\text {minor }}=30.96 \mathrm{~min}$; syn diasteroisomer (3ba) $\tau_{\text {major }}=23.48$ min., $\tau_{\text {minor }}=32.14$ min. anti:syn $73: 27$. ee anti $85 \%$. ee syn $65 \%$. HMRS calcd for $\mathrm{C}_{18} \mathrm{H}_{17} \mathrm{ClO}$ : 284.0978; found 284.0982. Daicel Chiralcel ODH column: hexane/i-PrOH 97.5:2.5, flow 
rate $0.50 \mathrm{~mL} / \mathrm{min}, 27^{\circ} \mathrm{C}, \lambda=214,250 \mathrm{~nm}$ : anti diasteroisomer $\tau_{\text {major }}=31.79 \mathrm{~min}, \tau_{\text {minor }}=43.47 \mathrm{~min}$; syn diasteroisomer $\tau_{\text {major }}=35.61 \mathrm{~min}, \tau_{\text {minor }}=50.09 \mathrm{~min}$.

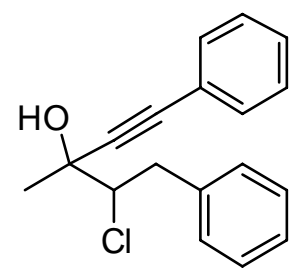

4-Chloro-3,7-dimethyl-1-phenyloct-1-yn-3-ol (3ca/4ca). $\mathrm{C}_{15} \mathrm{H}_{19} \mathrm{ClO} \mathrm{MW}=264.13 .{ }^{1} \mathrm{H}-\mathrm{NMR}\left(\mathrm{CDCl}_{3}\right.$, $300 \mathrm{MHz}) \delta: 0.88(\mathrm{~d}, 3 \mathrm{H}, J=6.6 \mathrm{~Hz}) ; 0.93(\mathrm{~d}, 3 \mathrm{H}, J=6.6 \mathrm{~Hz}) ; 1.59$ (min, s, 3H); 1.6 (maj, s, 3H); 2.0-1.40 (m, 5H); 2.43 (min, brs, 1H); 2.8 (maj, brs, 1H); 3.95 (maj, dd, 1H, J=2.1, $11.4 \mathrm{~Hz}$ ); 4.06 (min, dd, $1 \mathrm{H}, J=4.8,7.5 \mathrm{~Hz}) ; 7.30-7.20(\mathrm{~m}, 3 \mathrm{H}) ; 7.41-7.35(\mathrm{~m}, 2 \mathrm{H}) .{ }^{13} \mathrm{C}-\mathrm{NMR}\left(\mathrm{CDCl}_{3}, 75 \mathrm{MHz}\right)$

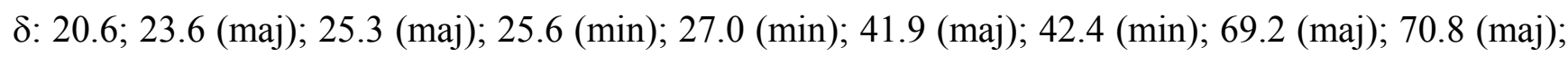
71.3 (min); 71.4 (min); 85.3 (maj); 86.1 (min); 89.3 (min); 89.9 (maj); 122.2; 128.2; 128.6; 131.8. The ee was determined by HPLC analysis Daicel Chiralcel OD column: hexane/i-PrOH 99:1, flow rate $0.50 \mathrm{~mL} / \mathrm{min}, 27^{\circ} \mathrm{C}, \lambda=214,250 \mathrm{~nm}$ : anti diasteroisomer (4ca) $\tau_{\text {major }}=17.58 \mathrm{~min}, \tau_{\text {minor }}=47.78 \mathrm{~min}$; syn diasteroisomer (3ca) $\tau_{\text {major }}=21.29 \mathrm{~min}, \tau_{\text {minor }}=50.02 \mathrm{~min}$. anti:syn 77:23. ee anti 81\%. ee syn $58 \%$. HMRS calcd for $\mathrm{C}_{15} \mathrm{H}_{19} \mathrm{ClO}: 264.1281$; found 264.1290 .

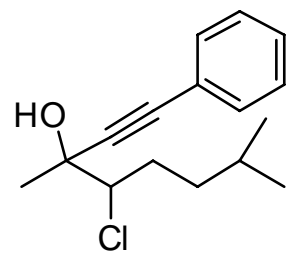

4-Chloro-3-methyl-1-phenyldec-1-yn-3-ol (3da/4da). $\mathrm{C}_{17} \mathrm{H}_{23} \mathrm{ClO} \mathrm{MW}=278.82 .{ }^{1} \mathrm{H}-\mathrm{NMR}\left(\mathrm{CDCl}_{3}, 300\right.$ $\mathrm{MHz}) \delta: 0.82(\mathrm{t}, 3 \mathrm{H}, J=7.2 \mathrm{~Hz}) ; 1.4-1.20(\mathrm{~m}, 8 \mathrm{H}) ; 1.60$ (s, 3H); 2.20-2.0 (m, 2H); 2.42 (maj, brs, $1 \mathrm{H}) ; 2.8$ (min, brs, $1 \mathrm{H}) ; 3.88$ (min, dd, $1 \mathrm{H}, J=2.1,11.1 \mathrm{~Hz}$ ); 3.98 (maj, dd, $1 \mathrm{H}, J=2.4,10.8 \mathrm{~Hz}$ ); 7.30-7.20 (m, 3H); 7.41-7.35 (m, 2H). ${ }^{13} \mathrm{C}-\mathrm{NMR}\left(\mathrm{CDCl}_{3}, 75 \mathrm{MHz}\right) \delta: 14.0$ (maj); 15.2 (min); 22.5; 25.7; 27.0; 28.6; 31.6; 30.6 (maj); 33.5 (min); 71.2 (maj); 71.3 (min); 84.6 (maj); 84.8 (min); 89.3 (min); 89.9 (maj); 122.2; 128.2; 128.6; 131.7. The ee was determined by HPLC analysis Daicel Chiralcel OD column: hexane/ $i$-PrOH 99.5:0.5, flow rate $0.50 \mathrm{~mL} / \mathrm{min}, 27{ }^{\circ} \mathrm{C}, \lambda=214,250 \mathrm{~nm}$ : anti diasteroisomer (4da) $\tau_{\text {major }}=23.20 \mathrm{~min}, \tau_{\text {minor }}=65.06 \mathrm{~min}$; syn diasteroisomer (3da) $\tau_{\text {major }}=30.40$ min, $\tau_{\text {minor }}=75.63$ min. anti:syn 78:22. ee anti 82\%. ee syn 55\%. HMRS calcd for $\mathrm{C}_{17} \mathrm{H}_{23} \mathrm{ClO}$ : 278.1437; found 278.1441.

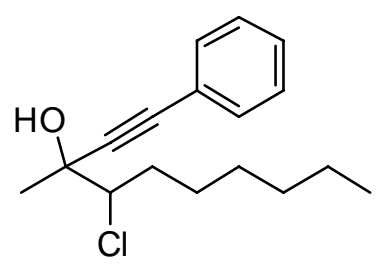

4-Chloro-3-methyl-1-phenylhex-1-yn-3-ol (3ea/4ea). $\mathrm{C}_{13} \mathrm{H}_{15} \mathrm{ClO} \mathrm{MW}=222.71 .{ }^{1} \mathrm{H}-\mathrm{NMR}\left(\mathrm{CDCl}_{3}\right.$, $300 \mathrm{MHz}) \delta: 1.16(\min , \mathrm{t}, 3 \mathrm{H}, J=6.9 \mathrm{~Hz}) ; 1.51(\mathrm{~min}, \mathrm{t}, 2 \mathrm{H}, J=6.9 \mathrm{~Hz}) ; 1.59$ (min, s, 3H); 1.68 (maj, 
s, 3H); 2.26-2.08 (m, 2H); 3.88 (min, dd, $1 \mathrm{H}, J=2.1,11.1 \mathrm{~Hz}$ ); 3.97 (maj, dd, $1 \mathrm{H}, J=2.1,11.4 \mathrm{~Hz}$ ); 7.35-7.22 (m, 3H); 7.45-7.30 (m, 2H). ${ }^{13} \mathrm{C}-\mathrm{NMR}\left(\mathrm{CDCl}_{3}, 75 \mathrm{MHz}\right) \delta: 12.0 ; 25.8$ (maj); 26.4 (maj); 26.9 (min); 27.0 (min); 71.3 (min); 73.1; 74.3 (maj); 84.9; 89.3 (min); 89.8 (maj); 122.2; 128.2; 128.5; 131.7. GC: 16.40 (min); 16.52 (maj). The ee was determined by HPLC analysis Daicel Chiralcel OD column: hexane $/ i$-PrOH 98:2, flow rate $0.50 \mathrm{~mL} / \mathrm{min}, 2{ }^{\circ} \mathrm{C}, \lambda=214,250 \mathrm{~nm}$ : anti diasteroisomer (4ea) $\tau_{\text {major }}=25.53 \mathrm{~min}, \tau_{\text {minor }}=51.00 \mathrm{~min}$; syn diasteroisomer (3ea) $\tau_{\text {major }}=34.73 \mathrm{~min}, \tau_{\text {minor }}=62.74 \mathrm{~min}$. anti:syn 75:25. ee anti 62\%. ee syn 42\%. GCMS: 15.07 (maj); 15.16 (min). HMRS calcd for $\mathrm{C}_{13} \mathrm{H}_{15} \mathrm{ClO}$ : 208.0811; found 208.0815.

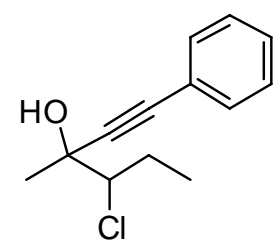

4-Chloro-3-methyl-1-phenyloct-1-yn-3-ol (3fa/4fa). $\mathrm{C}_{15} \mathrm{H}_{19} \mathrm{ClO} \mathrm{MW}=250.76 .{ }^{1} \mathrm{H}-\mathrm{NMR}\left(\mathrm{CDCl}_{3}\right.$, $300 \mathrm{MHz}) \delta$ : 0.98 (t, 3H, $J=7.2 \mathrm{~Hz}) ; 2.0-1.20(\mathrm{~m}, 6 \mathrm{H}) ; 1.70$ (s, 3H); 2.50 (min, brs, 1H); 2.87 (maj, brs, $1 \mathrm{H}) ; 3.85$ (maj, dd, $1 \mathrm{H}, J=2.4,11.1 \mathrm{~Hz}$ ); 3.98 (min, m, 1H); 7.35-7.22 (m, 3H); 7.45-7.30 (m, 2H). ${ }^{13} \mathrm{C}-\mathrm{NMR}\left(\mathrm{CDCl}_{3}, 75 \mathrm{MHz}\right) \delta: 13.9 ; 22.0 ; 25.7$ (min); 27.0 (maj); 29.2; 32.7 (min); 33.3 (maj); 71.1 (min); 72.7 (maj); 85.0; 89.3 (maj); 89.6 (min); 122.3; 128.3; 128.5; 131.7. GC: 18.9 (maj); 19.0 (min). The ee was determined by HPLC analysis Daicel Chiralcel OD column: hexane/ $i-\mathrm{PrOH}$ 98:2, flow rate $0.50 \mathrm{~mL} / \mathrm{min}, 2{ }^{\circ} \mathrm{C}, \lambda=214,250 \mathrm{~nm}$ : anti diasteroisomer (4fa) $\tau_{\text {major }}=15.77 \mathrm{~min}$, $\tau_{\text {minor }}=26.90 \mathrm{~min}$; syn diasteroisomer (3fa) $\tau_{\text {major }}=18.16 \mathrm{~min}, \tau_{\text {minor }}=28.48 \mathrm{~min}$. anti:syn 80:20. ee anti 83\%. ee syn 57\%. GCMS: 15.07 (maj); 15.16 (min). HMRS calcd for $\mathrm{C}_{13} \mathrm{H}_{15} \mathrm{ClO}$ : 208.0811; found 208.0815 .

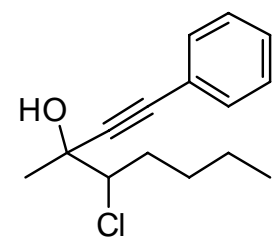

2-Fluoro-3-methyl-1,5-diphenylpent-4-yn-3-ol (3ga/4ga). $\mathrm{C}_{18} \mathrm{H}_{17} \mathrm{FO} \mathrm{MW}=268.33 .{ }^{1} \mathrm{H}-\mathrm{NMR}\left(\mathrm{CDCl}_{3}\right.$, $300 \mathrm{MHz}) \delta$ : $1.62(\mathrm{~d}, 3 \mathrm{H}, J=9.0 \mathrm{~Hz}) ; 3.25-2.96(\mathrm{~m}, 2 \mathrm{H}) ; 4.67-4.45(\mathrm{~m}, 1 \mathrm{H}) ; 7.28-7.20(\mathrm{~m}, 8 \mathrm{H})$; 7.45-7.38 (m, 2H); ${ }^{13} \mathrm{C}-\mathrm{NMR}\left(\mathrm{CDCl}_{3}, 75 \mathrm{MHz}\right) \delta: 25.9$ (d, $\left.J=123 \mathrm{~Hz}\right) ; 36.7$ (min, d, $\left.J=85 \mathrm{~Hz}\right) ; 36.9$ (maj, d, $J=85 \mathrm{~Hz}$ ); 70.2 (maj, d, $J=83 \mathrm{~Hz}$ ); 70.0 (min, d, $J=83 \mathrm{~Hz}$ ); 97.9 (min, $J=725 \mathrm{~Hz}$ ); 98.5 (maj, d, $J=725 \mathrm{~Hz}$ ): 122.0; 128.2; 128.5; 128.7; 129.2; 131.7; 137.34; The ee was determined by HPLC analysis Daicel Chiralcel OD column: hexane $/ i$-PrOH 97:3, flow rate $0.50 \mathrm{~mL} / \mathrm{min}, 27{ }^{\circ} \mathrm{C}$, $\lambda=214,250 \mathrm{~nm}$ : anti diasteroisomer (4ga) $\tau_{\text {major }}=30.23 \mathrm{~min}, \tau_{\text {minor }}=39.07 \mathrm{~min}$; syn diasteroisomer (3ga) $\tau_{\text {major }}=33.45 \mathrm{~min}, \tau_{\text {minor }}=40.72 \mathrm{~min}$. anti:syn $52: 48$. ee anti $56 \%$. ee syn $35 \%$. HMRS calcd for $\mathrm{C}_{18} \mathrm{H}_{17} \mathrm{FO}: 268.1273$; found 268.1268.

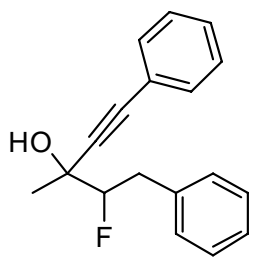


6-Bromo-2-chloro-3-methyl-1-phenylhex-4-yn-3-ol (3ab/4ab). $\mathrm{C}_{13} \mathrm{H}_{14} \mathrm{BrClO} \mathrm{MW}=301.61 .{ }^{1} \mathrm{H}-\mathrm{NMR}$ $\left(\mathrm{CDCl}_{3}, 300 \mathrm{MHz}\right) \delta: 1.59$ (min, s, 3H); 1.69 (maj, s, 3H); 2.6 (brs, 1H); 3.60-2.75 (m, 1H); 3.55-3.44 $(\mathrm{m}, 1 \mathrm{H}) ; 4.01(\mathrm{~s}, 2 \mathrm{H}) ; 4.13(\mathrm{t}, 1 \mathrm{H}, J=11.1 \mathrm{~Hz}) ; 7.40-7.20(\mathrm{~m}, 5 \mathrm{H}) .{ }^{13} \mathrm{C}-\mathrm{NMR}\left(\mathrm{CDCl}_{3}, 75 \mathrm{MHz}\right)$

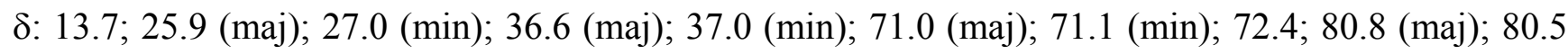
(min); 86.8 (min); 87.0 (maj); 126.8; 128.5; 129.3; 137.7 (min); 137.8 (maj). The ee was determined by HPLC analysis Daicel Chiralcel OD column: hexane $/ i$-PrOH 98:2, flow rate $0.60 \mathrm{~mL} / \mathrm{min}, 27^{\circ} \mathrm{C}$, $\lambda=214,250 \mathrm{~nm}$ : anti diasteroisomer (4ab) $\tau_{\text {major }}=38.36 \mathrm{~min}, \tau_{\text {minor }}=56.42 \mathrm{~min}$; syn diasteroisomer (3ab) $\tau_{\text {major }}=44.62 \mathrm{~min}, \tau_{\text {minor }}=65.56 \mathrm{~min}$. anti:syn $64: 36$. ee anti $66 \%$. ee syn 53\%. HMRS calcd for $\mathrm{C}_{13} \mathrm{H}_{14} \mathrm{BrClO}$ : 299.9917; found 299.9923.

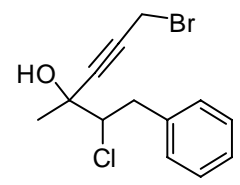

4-Chloro-3-methyl-5-phenyl-1-(trimethylsilyl)pent-1-yn-3-ol (3ac/4ac). $\mathrm{C}_{15} \mathrm{H}_{21} \mathrm{ClOSi} \mathrm{MW}=280.87$. ${ }^{1} \mathrm{H}-\mathrm{NMR}\left(\mathrm{CDCl}_{3}, 300 \mathrm{MHz}\right) \delta: 0.24(\mathrm{~s}, 9 \mathrm{H}) ; 1.68(\mathrm{~s}, 3 \mathrm{H}) ; 3.01(\mathrm{dd}, 1 \mathrm{H}, J=10.8,14.1 \mathrm{~Hz}) ; 3.52(\mathrm{~d}$, $1 \mathrm{H}, J=14.1 \mathrm{~Hz}$ ); 4.08 (maj, 1H, dd, $J=2.4,10.8 \mathrm{~Hz}$ ); 4.18 (min, m, 1H); 7.40-7.20 (m, 5H). ${ }^{13} \mathrm{C}-\mathrm{NMR}\left(\mathrm{CDCl}_{3}, 75 \mathrm{MHz}\right) \delta$ : -0.38 (min); -0.18 (maj); 27.4, 40.1; 70.9 (maj); 71.4 (min); 72.4; $90.5 ; 105.5 ; 126.8 ; 128.4 ; 129.3 ; 138.0$. The ee was determined by HPLC analysis Daicel Chiralcel OD column: hexane/i-PrOH 99.6:0.4, flow rate $0.50 \mathrm{~mL} / \mathrm{min}, 27{ }^{\circ} \mathrm{C}, \lambda=214,250 \mathrm{~nm}$ : anti diasteroisomer (4ac) $\tau_{\text {major }}=28.53 \mathrm{~min}, \tau_{\text {minor }}=27.34 \mathrm{~min}$; syn diasteroisomer (3ac) $\tau_{\text {major }}=34.77 \mathrm{~min}$, $\tau_{\text {minor }}=38.21 \mathrm{~min}$. anti:syn 75:25. ee anti $75 \%$. ee syn $62 \%$. HMRS calcd for $\mathrm{C}_{15} \mathrm{H}_{21} \mathrm{ClOSi}$ : 280.1050 ; found 280.1054 .

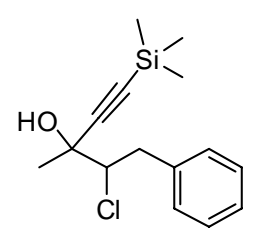

2-Chloro-3-methyl-1-phenylnon-4-yn-3-ol (3ad/4ad). $\mathrm{C}_{16} \mathrm{H}_{21} \mathrm{ClO} \mathrm{MW}=301.61 .{ }^{1} \mathrm{H}-\mathrm{NMR}\left(\mathrm{CDCl}_{3}\right.$, $300 \mathrm{MHz}) \delta: 0.94(\mathrm{t}, 3 \mathrm{H}, J=7.2 \mathrm{~Hz}) ; 1.60-1.40(\mathrm{~m}, 4 \mathrm{H}) ; 1.63$ (min, s, 3H); 1.65 (maj, s, 3H); 2.28 (t, 2H, $J=6.9 \mathrm{~Hz}$ ); 2.43 (min, brs, 1H); 2.60 (maj, brs, 1H); 2.85 (min, dd, 1H, $J=11.1,14.4 \mathrm{~Hz}$ ); 2.98 (maj, dd, $J=10.8,14.7 \mathrm{~Hz}$ ); 3.56-3.46 (m, 1H); 4.07 (maj, dd, 1H, $J=2.7,11.1 \mathrm{~Hz}$ ); 4.12 (min, dd, $J=2.4,10.8 \mathrm{~Hz}) ; 7.40-7.20(\mathrm{~m}, 5 \mathrm{H}) .{ }^{13} \mathrm{C}-\mathrm{NMR}\left(\mathrm{CDCl}_{3}, 75 \mathrm{MHz}\right) \delta: 13.5 ; 18.3 ; 21.9 ; 26.2(\mathrm{~min}) ; 26.9$ (maj); 30.6; 39.9 (min); 40.1 (maj); 70.8 (maj); 71.0 (min); 80.4 (maj); 80.7 (min); 126.7; 128.4; $129.2 ; 138.2$. The ee was determined by HPLC analysis Daicel Chiralcel OD column: hexane $i-\mathrm{PrOH}$ 99.6:0.4, flow rate $0.50 \mathrm{~mL} / \mathrm{min}, 27^{\circ} \mathrm{C}, \lambda=214,250 \mathrm{~nm}$ : anti diasteroisomer (4ad) $\tau_{\text {major }}=45.71 \mathrm{~min}$, $\tau_{\text {minor }}=49.73 \mathrm{~min}$; syn diasteroisomer (3ad) $\tau_{\text {major }}=59.01 \mathrm{~min}, \tau_{\text {minor }}=75.52 \mathrm{~min}$. anti:syn 83:17. ee anti $68 \%$. ee syn 41\%. HMRS calcd for $\mathrm{C}_{13} \mathrm{H}_{14} \mathrm{BrClO}$ : 299.9917 ; found 299.9923 .

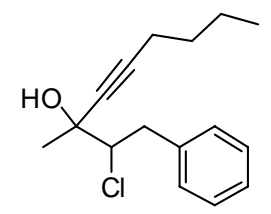




\section{Conclusions}

In conclusion, we have presented the first diastereoselective and enantioselective addition of phenylacetylene to chiral racemic chloroketones. The reaction provides access to highly functionalized products and the adducts were obtained in low yield and good stereoselection. The reactivity of chloroketones in the presence of chiral zinc catalyst can be explored with other zinc reagents taking advantage of the enhanced reactivity. Formation of quaternary and tertiary stereogenic centers from racemic chloroketones will be the subject of other studies from our laboratory.

\section{Acknowledgments}

PRIN (Progetto Nazionale Stereoselezioni in Chimica Organica: Metodologie ed Applicazioni), Bologna University, Fondazione Del Monte, and the European Commission through the project FP7-201431 (CATAFLU.OR) are acknowledged for financial support.

\section{References}

1. Luderer, M.R.; Bailey, W.F.; Luderer, M.R.; Fair; J.D.; Dancer, R.J.; Sommer, M.B. Asymmetric addition of achiral organomagnesium reagents or organolithium to achiral aldehydes or ketones: A review. Tetrahedron: Asymmetry 2009, 20, 981-998.

2. Hatano, M.; Ishihara, K. Recent progress in the catalytic synthesis of tertiary alcohols from ketones with organometallic reagents. Synthesis 2008, 1647-1675.

3. Cozzi, P.G.; Hilgraf, R.; Zimmerman, N. Acetylene in catalysis: enantioselective additions to carbonyl groups and imines and applications beyond. Eur. J. Org. Chem. 2004, 4095-4105.

4. Blay, G.; Monleon, A.; Pedro, J.R. Recent development in asymmetric alkynylation of imines. Curr. Org. Chem. 2009, 13, 1498-1539.

5. Trost, B.M.; Weiss, A.H. The enantioselective alkyne nucleophiles to carbonyl groups. Adv. Synth. Catal. 2009, 351, 963-983.

6. Cozzi, P.G.; Rudolph, J.; Bolm, C.; Norrby, P.O.; Tomasini, C. $\mathrm{Me}_{2} \mathrm{Zn}$-mediated addition of acetylene to aldehydes and ketones. J. Org. Chem. 2005, 70, 5733-5736.

7. Cozzi, P.G. Enantioselective alkynylation of ketones catalyzed by $\mathrm{Zn}(\mathrm{Salen})$ complexes. Angew. Chem. Int. Ed. 2003, 42, 2895-2898.

8. Zhang, G.-W.; Meng, W.; Ma, H.; Nie, J.; Zhang, W.-Q.; Ma, J.-A. Catalytic enantioselective alkynylation of trifluoromethyl ketones: Pronounced metal fluoride effects and implications of zinc-to-titanium transmetallation. Angew. Chem. Int. Ed. 2011, 50, 3538-3542.

9. Li, H.; Li, X.; Xue, F.; Huang, Y.; Jin, W.; Wan, B. Enantioselective alkynylzinc addition to carbonyl compounds by Tf-based sulfamide-amine alcohol catalysis. Chin. J. Chem. 2009, 27, 2013-2019.

10. Chen, C.; Hong, L.; Zhang, B.; Wang, R. Catalytic asymmetric addition of alkynylzinc reagents to ketones using polymer-supported chiral Schiff-base amino alcohols. Tetrahedron: Asymmetry 2008, 19, 191-196. 
11. Lu, G.; Li, X.; Li, Y.-M.; Kwong, F.Y.; Chan, A.S.C. Highly enantioselective catalytic alkynylation of ketones - a convenient approach to optically active propargylic alcohols. Adv. Synth. Catal. 2006, 348, 1926-1933.

12. Ni, M.; Wang, R.; Han, Z.-J.; Mao, B.; Da, C.-S.; Liu, L.; Chen, C. Synthesis of new C2-symmetrical bissulfonamide ligands and application in the enantioselective addition of alkynylzinc to aldehydes and ketones. Adv. Synth. Catal. 2005, 347, 1659-1665.

13. Lu, G.; Li, X.; Jia, X.; Chan, W.L.; Chan, A.S.C. Enantioselective alkynylation of aromatic ketones catalyzed by chiral camphorsulfonamide ligands. Angew. Chem., Int. Ed. 2003, 42, 5057-5058.

14. Roman, B.I.; De Kimpe, N. Stevens, C.V. Synthesis of $\beta-, \gamma-, \delta-\varpi-$ Halogenated Ketones and Aldehydes. Chem. Rev. 2010, 110, 5914-5988.

15. Brun, E.M.; Gil, S.; Mestres, R.; Parra, M.; Villar, F. Enediolates and dienediolates of carboxylic acids in synthesis. Synthesis of $\beta, \gamma$-epoxyacids from $\alpha$-chloroketones. Tetrahedron Lett. 1998, 39, 1055-1058.

16. Li, F.Q.; Zhong, S.; Lu, G.; Chan, A.S.C. Zn-Salen catalyzed asymmetric alkynylation of alkyl acylsilanes. Adv. Synth. Catal. 2009, 351, 1956-1960.

17. Bernard, D.; Doutheau, A.; Gore, J.; Moulinoux, J.; Quemener, V.; Chantepie, J.; Quash, G. $\gamma$-Amino- $\alpha$-acetylinic epoxides. Preparation and biological activity due to an aldehyde riductase inhibition. Tetrahedron 1989, 45, 1429-1439.

18. Chérest, M.; Felkin, H.; Prudent, N. Torsional strain involving partial bonds. The stereochemistry of the lithium aluminium hydride reduction of some simple open-chain ketones, Tetrahedron Lett. 1968, 2199-2204.

19. Anh, N.T. Regio and stereoselectivities in some nucleophilic reactions. Top. Curr. Chem. 1980, 88, 145-162.

20. Anh, N.T.; Eistenstein, O. Theoretical interpretation of 1-2 asymmetric induction - Importance of antiperiplanarity. Nouv. J. Chim. 1977, 1, 61-70.

21. Wong, S.S.; Paddon-Row, M.N. Theoretical evidence in support of the Anh-Eisenstein electronic model in controlling $\pi$-facial stereoselectivity in nucleophilic additions to carbonyl compounds. J. Chem. Soc. Chem. Commun. 1990, 456-458.

22. Smith, R.J.; Trzoss, M.; Böhl, M.; Bienz, S. The Cram rule revisited once more - Revision of the Felkin-Anh model. Eur. J. Org. Chem. 2002, 2770-2775.

23. De Kimpe, N.; Brunet, P. A convenient synthesis of 3-chloro-2-alkanones. Synthesis 1990, 7, 595-596.

24. Dekeukeleire, S.; D’hooghe, M.; Törnroos, K.W.; De Kimpe, N. Stereoselective synthesis of chiral 4-(1-chloroalkyl)- $\beta$-lactams starting from amino acids and their transformation into functionalized chiral azetidines and pyrrolidines. J. Org. Chem. 2010, 75, 5934-5940.

25. Cornforth, J.W.; Cornforth, R.H.; Mathew, K.K. A general stereoselective synthesis of olefins. J. Chem. Soc. 1959, 112-127.

26. Brinkmann, H.; Hoffmann, R.W. Stereoselective synthesis of alcohols. XXXV Addition of $E$ and $Z$ crotylboronate to chiral $\alpha$ substituted aldehydes. Chem. Ber. 1990, 123, 2395-2401.

27. Frenking, G.; Köhler, K.F.; Reetz, M.T. On the origin of $\pi$-facial diastereoselectivity in nucleophilic additions to chiral carbonyl compounds. 2. Calculated transition state structures 
for the addition of nucleophiles to propionaldehyde 1, chloroacetyldehyde 2, and 2chloropropionaldehyde 3. Tetrahedron 1991, 47, 9005-9018.

28. Mengel, A.; Reiser, O. Around and beyond the Cram rule. Chem. Rev. 1999, 99, 1191-1223.

29. Concellòn, J.M.; Rodrìguez-Solla, H.; Simal, C.; Gòmez, C. A convenicent syntehsis of $Z$ allylsilanes with good stereoselectivity promoted by $\mathrm{SmI}_{2}$. Synlett 2007, 75-78.

30. Kang, B.; Britton, R. A general method for the synthesis of non-racemic trans epoxide containing insect sex pheromones. Org. Lett. 2007, 9, 5083-5086.

31. The sense of the absolute configuration is reversed. However, also in the case of choroketone, $(S)$ configurated stereogenic centers are formeddue to priority of the halogenated chain.

32. Hutchinson, J.; Sandford, G.; Vaughan, J.F.S. Alkylation and decarboxylation of ethyl 2-fluoro-3 oxobutanoate as a route to functionalized $\alpha$-fluoro ketones. Tetrahedron 1998, 54, 2867-2876.

(C) 2011 by the authors; licensee MDPI, Basel, Switzerland. This article is an open access article distributed under the terms and conditions of the Creative Commons Attribution license (http://creativecommons.org/licenses/by/3.0/). 